\title{
Pre-emptive analgesia with ketamine, morphine and epidural lidocaine prior to total knee replacement
}

Chih-Shung Wong MD, PHD, Chih-Chen Lu MD, Chen-Hwan Cherng MD, DMSC, Shung-Tai Ho MD

Purpose: Pre-emptive analgesia can improve postoperative pain management. The purpose of this study was to examine the effectiveness of ketamine as a pre-emptive analgesic as previous studies have shown the involvement of N-methyl-D-Aspartate (NMDA) receptor in neuroplasticity.

Methods: Forty-five ASA I-2 patients, undergoing unilateral total knee replacement were studied. In the study groups, epidural lidocaine was used as the primary anaesthestic. Patients received ketamine + morphine epidurally 30 min either before (group EB) or after skin incision (group EA). Group G patients received general anaesthesia and ketamine + morphine were given 30 min after skin incision via an epidural catheter used for postoperative pain control. Epidural morphine and ketamine in lidocaine was given to all patients at the end of surgery and every $12 \mathrm{hr}$ for three days for analgesia supplemented with PCA morphine. The time until first PCA trigger, morphine consumption, pain scores, satisfaction scores, and morphine related side effects were recorded at 6, 12, 24, 48 and $72 \mathrm{hr}$ after surgery. Results: Epidural ketamine plus morphine with lidocaine before surgical incision produced better pain relief and patient satisfaction than when given after incision. A longer time to PCA and decreased morphine consumption were observed in group EB than in group $\mathrm{G}$. In group EA, epidural anaesthesia also produced some pre-emptive analgesic effect compared with general anaesthesia shown by decreased morphine consumption.

Conclusions: Administration of ketamine plus morphine with epidural lidocaine anaesthesia before surgery provided improved postoperative analgesia compared with general anaesthesia alone or when analgesics were given after skin incision.

Objectif : La coanalgésie (pre-emptive analgesia) peut amélıorer le traitement de la douleur postopératorre. Lobjectif de cette étude était d'évaluer l'efficacité de la kétamine comme analgésique préventif en s'appuyant sur plusieurs études qui ont montré l'influence des récepteurs du N-méthyl-D-aspartate (NMDA) sur la neuroplasticité. Méthodes : Quarante-cinq patients ASA I et 2 opérés pour un remplacement total d'un seul genou participaient à l'étude. Dans ce groupe, la lidocaïne épidurale constituart l'anesthésie principale. Les patients recevaient de la kétamine avec de la morphine $30 \mathrm{~min}$ soit avant (groupe EB) soit après l'incision de la peau (groupe EA). Le groupe G recevait une anesthésie générale et de la kétamine avec de la morphine après lincision par le cathéter épidural utilisé pour le contrôle de la douleur postopératoire. De la morphine associée à de la kétamine dans de la lidocaïne épidurale était administrée à tous les patients à la fin de la chirurgie et à toutes les 12 heures pendant trois jours pour l'analgésie avec ajout de morphine en PCA. Le moment de la première activation de la PCA la consommation de morphine. les scores de douleur et les effets secondaires étaient enregistrés 6, 12, 24, 48 et $72 \mathrm{~h}$ après la chirurgle Résultats : L'association kétamine-morphine épidurale avec de la lidocaine administrée avant lincision procure un meilleur soulagement et une satisfaction plus grande au patient que lorsqu'elle est administrée après l'incision. Dans le groupe EB, un délai était plus long avant la PCA et la consommation de morphine était plus fable que dans le groupe G. Dans le groupe EA. l'anesthésie épidurale produisait aussi une analgésie préventive contrairement à l'anesthésie générale comme l'a montré une diminution de la consommation de morphine.

Conclusion : L'administration avant la chirurgie de la kétamine associée à la morphine avec l'anesthésie épidurale à la lidocaïne améliore l'analgésie comparativement à l'anesthésie générale seule ou lorsque des analgésiques sont administrés après l'incision de la peau.

From the Department of Anesthesiology, National Defense Medical Center and Tri-Service General Hospital, \#8, Section 3, Tingchow Road, Taipei, Taiwan, Republic of China.

Address correspondente to: Dr. Chils-Shung Wong.Tel: 886-2-3652334; Fax: 886-2-3688781.

Supported by grants from National Science Council (NSC 84-2331B016-087) and Institure of Physics Academia Sinica (IBMS-CRC85S06) of Taiwan, Republic of China.

Accepted for publication September 2, 1996.

CAN J ANAESTH 1997/44:1/ pp 31-37 
S ENSORY stimuli induced by tissue destruction during an operation can trigger prolonged excitability in the central nervous system, which, in turn, enhances the responses of nociceptive neurons in the spinal cord and complicates the postoperative pain control. ${ }^{1}$ Therefore, preventing sensitization of nociceptive neurons in the spinal cord during surgery may facilitate postoperative pain management. McQuay et al. have shown that blocking noxious stimuli before surgical incision provides better pain relief with lower analgesic requirement than administering analgesics after surgery. ${ }^{2}$ Coderre and Melzack also demonstrated that spinal anaesthesia or blocking the neural afferent fibres before tissue injury could prevent heat injury induced primary and secondary hyperalgesia. ${ }^{3}$ In an electrophysiological study, Dickenson and Sullivan showed that intrathecal opioid administration before a formalin injection produced $70 \%$ more inhibition of the $\mathrm{C}$-fibre response than the same dose injected intrathecally after the formalin injection. ${ }^{4}$ However, some contradictory reports found that repetitive $\mathrm{C}$-fibre stimulation induced spinal cord nociceptive neuron sensitization is NMDA receptor-mediated and is less sensitive to intrathecal opioids injection. ${ }^{5-6}$ Some studies showed that post-injury nociceptive behaviour might be linked to central sensitization of the nociceptive neurons that might, at least in part, be mediated by central NMDA receptor activation. ${ }^{7-9}$ Electrically or chemically stimulated central hyperexcitability can be prevented or reversed by a non-competitive MK-801 or a competitive D-CPP NMDA antagonist. ${ }^{10}$ Recently, we demonstrated that ketamine, a non-competitive NMDA antagonist, potentiated morphine analgesic effects in postoperative patients. ${ }^{11}$ In that study, we found that ketamine administered before surgical incision produced better analgesia. Therefore, in the present study, we examined the effect of epidural ketamine in preemptive analgesia.

\section{Methods}

This study was approved by the Protection of Human Subjects Institutional Review Board of National Defense Medical Center. Written informed consent from all patients was obtained before including in the study. Patients who received opioids or non-steroidal anti-inflammatory drugs (NSAIDs) within one week of surgery were excluded from the study. Forty-five patients (ASA 1 and 2, of either sex) who underwent unilateral total knee joint replacement were included. Random sampling was used to divide patients into three groups: group G, general anaesthesia + post-incisional ( $30 \mathrm{~min}$ after skin incision) epidural morphine $(1.5 \mathrm{mg})$ and ketamine $(20 \mathrm{mg})$; group $\mathrm{EB}$, pre-incisional ( $30 \mathrm{~min}$ before skin incision) morphine + ketamine with epidural lidocaine anaesthesia; group EA, post-incisional (30 min after skin incision) morphine + ketamine with epidural lidocaine anaesthesia (Table I).

An epidural catheter was inserted at the $\mathrm{L}_{1-2}$ or $\mathrm{L}_{2-3}$ level and advanced $5 \mathrm{~cm}$ into the epidural space. Diazepam 5-10 mg iv was given to all patients for amnesia. No patient received opioids or NSAIDs during surgery. All patients, except those in group G, breathed spontaneously with oxygen, $5 \mathrm{~L} \cdot \mathrm{min}^{-1}$, via mask throughout surgery. General anaesthesia was induced with $3-5 \mathrm{mg} \cdot \mathrm{kg}^{-1}$ thiopentone ip and tracheal

TABLE I The study protocol of the three patient groups.

\begin{tabular}{llll}
\hline & Treatment & Treatment & Treatment \\
\hline $\begin{array}{l}\text { Group G } \\
\text { (General Anaesthesia) }\end{array}$ & Saline $15 \mathrm{ml}$ & $\begin{array}{l}\text { Saline } 10 \mathrm{ml} \\
\text { Morphine } 1.5 \mathrm{mg} \\
\text { Ketamine } 20 \mathrm{mg}\end{array}$ & $\begin{array}{l}\text { *Epidural } \\
\text { Pain Control }\end{array}$ \\
$\begin{array}{l}\text { Group EA } \\
\text { (Epidural Anaesthesia) }\end{array}$ & $2 \%$ Lidocaine $15 \mathrm{ml}$ & $\begin{array}{l}2 \% \text { Lidocaine } 10 \mathrm{ml} \\
\text { Morphine } 1.5 \mathrm{mg} \\
\text { Ketamine } 20 \mathrm{mg}\end{array}$ & $\begin{array}{l}\text { *Epidural } \\
\text { Pain Contral }\end{array}$ \\
$\begin{array}{l}\text { Group EB } \\
\text { (Epidural Anaesthesia) }\end{array}$ & $\begin{array}{l}2 \% \text { Lidocaine } 15 \mathrm{ml} \\
\text { Morphine } 1.5 \mathrm{mg} \\
\text { Ketamine } 20 \mathrm{mg}\end{array}$ & $2 \%$ Lidocaine $10 \mathrm{ml}$ & *Epidural \\
Time & $\begin{array}{l}\text { Pain Control } \\
\text { epidural skin } \\
\text { catheter incision } \\
\text { insertion }\end{array}$ & 30 & 60 \\
\hline
\end{tabular}

*A unified epidural pain control regimen with $\mathrm{l} \mathrm{mg}$ morphine and $10 \mathrm{mg}$ ketamine in $10 \mathrm{ml}$ of lidocaine $0.32 \% \mathrm{q} 12 \mathrm{hr}$. 
intubation was facilitated with $1.5-2 \mathrm{mg} \cdot \mathrm{kg}^{-1}$ succinylcholine $i v$. General anaesthesia was maintained with isoflurane and nitrous oxide in oxygen (1.5L:1.5L $\left.\cdot \mathrm{min}^{-1}\right)$. Pancuronium $\left(0.08-0.1 \mathrm{mg} \cdot \mathrm{kg}^{-1}\right.$ ) was used for muscle relaxation. Standard monitoring included pulse oximeter, ECG, and intra-arterial pressure via a radial artery catheter. Crystalloid infusion and 10-20 mg ephedrine were used to maintain systolic blood pressure at $80-120 \mathrm{mmHg}$. For patients receiving general anaesthesia, residual neuromuscular block was antagonized with $0.05 \mathrm{mg} \cdot \mathrm{kg}^{-1}$ neostigmine and $0.02 \mathrm{mg} \cdot \mathrm{kg}^{-1}$ atropine after surgery was completed, and the trachea was extubated when the patient was breathing spontaneously.

A unified epidural pain control regimen of $1 \mathrm{mg}$ morphine and $10 \mathrm{mg}$ ketamine in $10 \mathrm{ml}$ of lidocaine $0.32 \%$ was given every $12 \mathrm{hr}$ for postoperative pain relief starting at the end of surgery. Intravenous patient control analgesia (PCA) morphine was applied for supplementary pain relief as required. We recorded the time to first PCA trigger, total PCA morphine requirement, visual analog pain scores, incident pain scores during the active range of motion, satisfaction scores and the incidence of pain control side effects at 6,12 , 24,48 , and $72 \mathrm{hr}$ postoperation. We evaluated pain intensity using a $100 \mathrm{~mm}$ visual analogue scale (VAS). Satisfaction scores were evaluated by numeric rating scores ( 5 to 1 , from the most to the least satisfaction). Respiratory depression was defined as the respiratory rate less than 10 breathes per min. All the assessments were on a double-blind basis by an anaesthetist. Side effects were treated with medications if necessary.

Results are presented as mean \pm SEM. The statistical analysis used was the Kruskal-Wallis test with the Dunn procedure. A value of $P<0.05$ was considered statistically significant.

\section{Results}

There were no demographic differences among the three groups (Table II). There were also no differences in vital signs ( $\mathrm{HR}, \mathrm{BP}$ and $\mathrm{SpO}$ ) among groups during surgery. Patients pretreated with morphine plus ket-

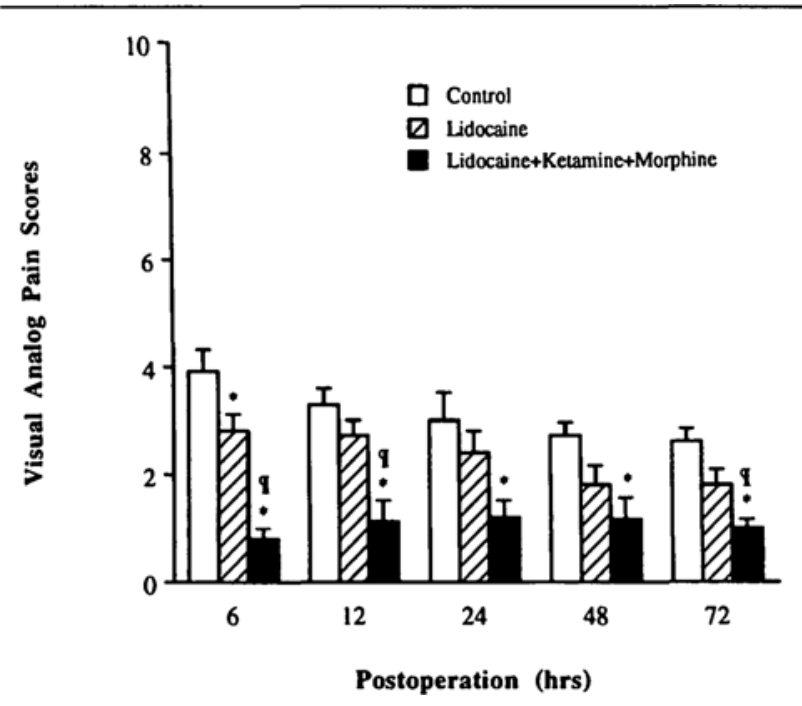

FIGURE I Visual analog pain scores (VAS) over three days after surgery. Group $G$ patients received general anaesthesia and epidural ketamine plus morphine, 30 rnin after skin incision. Patients in group EA and EB received epidural lidocaine anaesthesia and ketamine plus morphine $30 \mathrm{~min}$ before $(E B)$ or after $(E A)$ surgical incision respectively. Mean $\pm S E M .{ }^{*} P<0.05$ (compared with group $G$ ); $\mathbb{I} P<0.05$ (compared with group EA).

amine with lidocaine epidural anaesthesia (group EB) showed the best pain relief among the three groups over the three days after surgery (Figure 1 ). The greatest difference in pain relief was observed during the first six hours with VAS pain scores of $0.82 \pm 0.09$ (group $\mathrm{EB}, P<0.05$, compared with group $\mathrm{G}$ and EA), $2.87 \pm$ 0.18 (group EA, $P<0.05$, compared with group $\mathrm{G}$ ) and $3.94 \pm 0.41$ (group G). Better pain relief was also observed in group EB patients than in group EA patients $(P<0.05)$ at 12 and $72 \mathrm{hr}$ after surgery (Figure 1). All patients started active range of motion on the second day after surgery. Better pain relief was also observed in group $\mathrm{EB}$ patients who received epidural lidocaine anaesthesia with ketamine plus morphine treatment before surgery with a VAS pain score of $2.95 \pm 0.35(P<0.05$, compared with groups $\mathrm{G}, 4.82 \pm$ 0.57 and EA, $4.66 \pm 0.35$ ) (Table III). In group G, there were three patients who could not tolerate exer-

TABLE II Demographic Data.

\begin{tabular}{llllll}
\hline & Male/Female & Age $(\mathrm{yr})$ & Weight $(\mathrm{kg})$ & Height $(\mathrm{cm})$ & $\begin{array}{l}\text { Operation } \\
\text { Duration }(\mathrm{br})\end{array}$ \\
\hline Group G & $8 / 7$ & $59.3(13.4)$ & $60.2(11.2)$ & $156.6(7.2)$ & $1.3(0.5)$ \\
Group EA & $7 / 8$ & $62.6(10.6)$ & $57.6(6.3)$ & $155.4(7.4)$ & $1.6(0.3)$ \\
Group EB & $7 / 8$ & $61.6(6.0)$ & $58.2(8.3)$ & $157.9(8.5)$ & $1.5(0.5)$ \\
\hline
\end{tabular}

Group G: General anaesthesia with ketamine plus morphine epidural injection 30 min after skin incision; Group EA: Epidural lidocaine anaesthesia with ketamine plus morphine 30 epidural injection $30 \mathrm{~min}$ after skin incision; Group EB: Co-administered ketamine plus morphine with epidural anaesthesia 30 min before skin incision. 
TABLE III Effects of preemptive treatments on preemptive analgesia.

\begin{tabular}{lllll}
\hline & $\begin{array}{l}\text { Time to lst } \\
\text { PCA trigger }(\mathrm{br})\end{array}$ & $\begin{array}{l}\text { Total morphine } \\
\text { consumption }(m g)\end{array}$ & $\begin{array}{l}\text { Incident } \\
\text { Pain Scores }\end{array}$ & $\begin{array}{l}\text { Satisfaction } \\
\text { Scores }\end{array}$ \\
\hline Group G & $2.24(0.57)$ & $15.0(1.4)$ & $4.82(0.57)$ & $3.45(0.16)$ \\
Group EA & $3.04(0.67)$ & $8.1(0.6)^{\mathrm{b}}$ & $4.66(0.35)$ & $4.05(0.12)$ \\
Group EB & $7.38(2.08)^{\mathrm{a}}$ & $4.0(0.7)^{\mathrm{b}, \mathrm{c}}$ & $2.95(0.35)^{\mathrm{d}, \mathrm{e}}$ & $4.80(0.13)^{\mathrm{f}, \mathrm{B}}$ \\
\hline
\end{tabular}

a. $P<0.05$ (compared with groups $G$ and EA); b. $P<0.01$ (compared with group G); c. $P<0.05$ (compared with groups EA); d. $P<$ 0.005 (compared with group G); e. $P<0.05$ (compared with groups EA); f. $P<0.001$ (compared with group G); g. $P<0.05$ (compared with group EA).

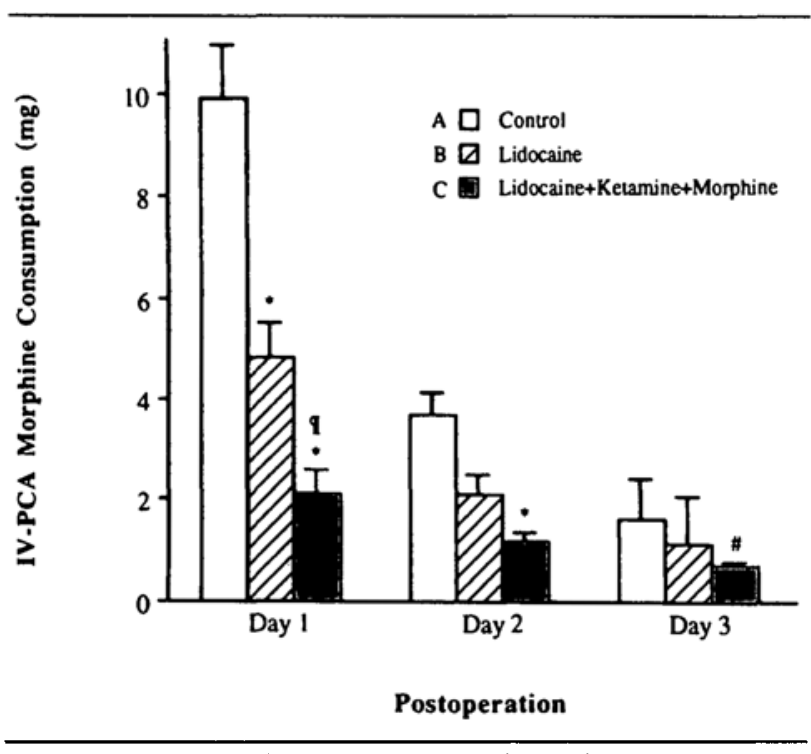

FIGURE 2 Total additional morphine demands over three days after surgery. Mean \pm SEM. ${ }^{*} P<0.001$ (compared with control group G); I $P<0.05$ (compared with group EA); $P<0.05$ (compared with group $G$ ).

cise at the first exercise attempt. Additionally, patients in group EB consumed the smallest dose of PCA morphine over the three days (Figure 2). The least PCA morphine consumption $(4.0 \pm 0.07 \mathrm{mg}, P<0.01$ and $P<0.05$ compared with group $\mathrm{G}, 15 \pm 1.4 \mathrm{mg}$ and $\mathrm{EA}, 8.1 \pm 0.6 \mathrm{mg}$ ) was observed in group EB patients during the three days postoperation (Table III). Moreover, a longer time elapsed before the first PCA trigger was seen in group $\mathrm{EB}(7.38 \pm 2.08 \mathrm{hr})$ than in group G patients $(2.24 \pm 0.57 \mathrm{hr}, P<0.05)$. Patients receiving epidural anaesthesia without ketamine and morphine pretreatment (group EA) also consumed less PCA morphine $(3.75 \pm 0.71 \mathrm{mg}$, $)$ than group $\mathrm{G}$ patients $(9.87 \pm 0.94 \mathrm{mg}, P<0.001)$ on day 1 (Figure 2).

Opioid-associated side effects were observed at a high frequency in group $G$ especially on day 1 after surgery (Table IV). This may have resulted from the higher doses of PCA morphine (Table III). Urinary retention was not recorded in this study because most patients had a Foley catheter in situ. No patient expe-
TABLE IV Side effects from postoperative pain control one day after surgery.

\begin{tabular}{lllll}
\hline & Nausea & Vomiting & Drowsiness & Pruritus \\
\hline Group G & $10 / 15$ & $7 / 15$ & $9 / 15$ & $3 / 15$ \\
Group EA & $6 / 15$ & $6 / 15$ & $6 / 15$ & $2 / 15$ \\
Group EB & $3 / 15$ & $2 / 15$ & $1 / 15$ & $1 / 15$ \\
\hline
\end{tabular}

rienced respiratory depression. Two patients (one in group $\mathrm{G}$ and the other in group EB) suffered ketamine-induced psychomimetic effects and were excluded from the study. The psychomimetic emergencies were attenuated and lasted for two hours after $5 \mathrm{mg}$ diazepam $i p$.

\section{Discussion}

The present study shows that inducing analgesia, in particular with ketamine plus morphine, before surgical incision produced better postoperative analgesia than giving analgesia after incision. Without analgesic pretreatment, patients receiving epidural anaesthesia (group EA) also experienced better postoperative pain relief and required less PCA morphine than patients who received general anaesthesia (group G). These results agree with results of pre-emptive analgesic effect obtained in previous studies. ${ }^{12-14}$ Pretreatment of ketamine plus morphine with epidural anaesthesia (group EB) demonstrated the longest time to the first PCA trigger after surgery, the lowest total PCA morphine consumption, the best postoperative pain relief and the highest patient satisfaction scores. The pain relief of group EB patients was observed to be markedly superior in the first six hours after surgery. On the first postoperative day, a higher incidence of drowsiness was observed in groups $\mathrm{G}$ and EA. This might have been due to higher doses of PCA morphine consumed and suggests that the better pain relief of combined ketamine-morphine-lidocaine pretreatment is not due to over sedation by the drugs. Moreover, from the pharmacokinetic point of view, patients in group $G$ and $E A$ who received the same treatment as group EB patients, but at $\mathbf{3 0 ~ m i n ~ a f t e r ~}$ incision, should have had higher analgesics concentrations in the cerebrospinal fluid (CSF) and better post- 
operative pain relief. Thus, pre-emptive analgesia plays a role in the improved postoperative analgesia in group EB patients.

Spinal anaesthesia, major peripheral nerve block, and operative field local anaesthetic infiltration all reduced postoperative analgesic requirements and improved postoperative pain relief. ${ }^{14-15}$ Low doses of morphine pretreatment inhibit C-fibre induced windup while higher doses are needed if morphine is given after injury. ${ }^{15}$ Abram and Yaksh showed that intrathecal morphine, but not inhalation of isoflurane, reduced phase II flinching in a formalin injected rat paw. ${ }^{13}$ The present study showed epidural anaesthesia co-administered with morphine offered a pre-emptive analgesic effect.

There are some contradictory results. In one study, pre-emptive analgesia was not observed in patients pretreated with parenteral alfentanil at conventional doses. ${ }^{16}$ Richmond et al. also found that patients with morphine treatment before surgery experienced more severe movement-related pain than patients receiving morphine after surgery. ${ }^{14}$ In addition, Dahl et al. revealed that there was no difference in the amount of additional morphine requested or pain scores during rest or ambulation at any time of measurement between patients who received continuous extradural analgesia with bupivacaine and morphine before than in those who received analgesia after surgery. ${ }^{17}$ In all these studies, the different results might have been due to the fentanyl and bupivacaine test-doses, which were employed in both control and the study groups.

According to Woolf and Chong's theory, the optimal form of pre-emptive analgesia not only begins before surgical incision, but also continuously prevents noxious stimuli from over-exciting the nociceptive system, before, during and after surgery, to achieve better postoperative pain control. ${ }^{1}$ However, Dahl et al. revealed that there was no difference in pain score at rest or at mobilization, or in request for additional analgesics in total knee joint replacement patients receiving bupivacaine epidural anaesthesia and followed by. a 48 -hr epidural bupivacaine-morphine treatment. ${ }^{18}$ Pryle $e t a l$. also demonstrated that preoperative epidural bupivacaine block did not produce better pain scores or diminish the need for additional analgesics in the postanaesthetic recovery room in abdominal hysterectomy patients. ${ }^{13}$ The reason for the small or non-existent effect of pre-emptive analgesia in these clinical studies might have been that pretreatment with local anaesthetics or opioids does not provide a sufficient blockade against the afferent input during and after surgery. Furthermore, splanchnic block in combination with epidural anaesthesia was found more effective than epidural anaesthesia alone for pre-emptive analgesia after visceral surgery. ${ }^{18}$ Thus, multimodal pre-emptive analgesia, such as used in this study, might be necessary to produce enough noxious input block during and after surgery to prevent central nociceptor sensitization.

Recently, the NMDA receptor has been found to play a role in nociceptor sensitization in the spinal cord. ${ }^{19}$ NMDA and inflammatory agent-induced hyperalgesia can be blocked by NMDA receptor antagonists. ${ }^{20-23}$ Yamamoto and Yaksh found that intrathecal injections of the NMDA receptor antagonists MK-801, D-AP5 or ketamine eliminated the occurrence of a hyperalgesic state in rats suffering from unilateral sciatic nerve constriction injury. ${ }^{24}$ In humans, surgical trauma may lead to comparable alterations in sensory processing, resulting in amplification and prolongation of postoperative pain which might also relate to the NMDA receptor activation. ${ }^{25,26}$ Tverskoy et al. demonstrated that fentanyl and ketamine pre-emptively decreased postoperative wound hyperalgesia. ${ }^{27}$ In addition, Roytblat et al. showed that ip low-dose ketamine administration before surgical stimulation produced better postoperative pain relief and reduced the dose of morphine required. ${ }^{28}$ The present study also found that pretreatment with ketamine plus morphine and lidocaine epidural anaesthesia produced the best postoperative analgesia. Neurotoxic effects of intrathecal ketamine have been reported with the preservative chlorobutanol, ${ }^{29}$ but not with benzethonium chloride. ${ }^{30,31}$ Following our previous study, no neurological deficits have been reported in the follow up of three years. ${ }^{11}$

The present study showed that ketamine plus morphine treatment before skin incision with epidural lidocaine anaesthesia provided an ideal pre-emptive postoperative analgesic effect in TKR patients. This treatment provided the best pain control with the lowest PCA morphine requirement under the same epidural pain control regimen. The best pain relief during active range of motion and the best satisfaction scores were also in group EB patients. Epidural anaesthesia also offers some pre-emptive analgesia compared with general anaesthesia. These results suggest that NMDA receptor antagonism, in addition to morphine pretreatment and regional local anaesthetic block, plays a role in preventing sensitization of nociceptive neurons in the spinal cord. In conclusion, the present study showed that epidural anaesthesia combined with a multimodal treatment of subanalgesic doses of ketamine and morphine before surgery provides the best pre-emptive analgesic effect. 


\section{References}

1 Woolf $C J$, Chong $M$-S. Preemptive analgesia-treating postoperative pain by preventing the establishment of central sensitization. Anesth Analg 1993; 77: 362-79.

2 McQuay HJ, Carroll D, Moore RA. Postoperative orthopaedic pain - the effect of opiate premedication and local anaesthetic blocks. Pain 1988; 33: 291-5.

3 Coderre T\}, Melzack R. Cutaneous hyperalgesia: contributions of the peripheral and central nervous systems to the increase in pain sensitivity after injury. Brain Res 1987; 404: 95-106.

4 Dickenson $A H$, Sullivan AF. Subcutaneous formalininduced activity of dorsal horn neurons in the rat: differential response to an intrathecal opiate administered pre or post formalin. Pain 1987; 30: 349-60.

5 Dickenson AH, Sullivan AF. Evidence for a role of the NMDA receptor in the frequency dependent potentiation of deep rat dorsal horn nociceptive neurones following C fiber stimulation. Neuropharmacology 1987; 26: 1235-8.

6 Chapman V, Haley JE, Dickenson AH. Electrophysiologic analysis of preemptive effects of spinal opioids on $\mathrm{N}$-methyl-D-aspartate receptor-mediated events. Anesthesiology 1994; 81: 1429-35.

7 Davar G, Hama A, Daykin A, Vos B, Maciewicz $R$. MK-801 blocks the development of thermal hyperalgesia in a rat model of experimental painful neuropathy. Brain Res 1991; 553: 327-30.

8 Seltzer $Z$, Cobn S, Ginzburg R, Beilin B. Modulation of neuropathic pain behavior in rats by spinal disinhibition and NMDA receptor blockade of injury discharge. Pain $1991 ; 45:$ 69-75.

9 Woolf CJ, Thompson SWN. The induction and maintenance of central sensitization is dependent on $\mathrm{N}$ methyl-D-aspartic acid receptor activation: implications for the treatment of post-injury pain hypersensitivity states. Pain 1991; 44: 293-9.

10 Dubner $R$. Neuronal plasticity and pain following peripheral tissue inflammation or nerve injury. In: Bond MR, Charlton JE, Woolf CJ (Eds.). Proceedings of the 6th World Congress on Pain. Amsterdam: Elsevier 1991; 263-76.

11 Wong C-S, Liaw W-J, Tung C-S, Su $\Upsilon$-F, Ho S-T. Ketamine potentiates analgesic effect of morphine in postoperative epidural pain control. Reg Anesth 1996; (in press).

12 Pryle BJ, Vanner $R G$, Enriquez $N$, Reynolds $F$. Can preemptive lumbar epidural blockade reduce postoperative pain following lower abdominal surgery? Anaesthesia 1993; 48: 120-3.

13 Abram SE, raksh TL. Morphine, but not inhalational anesthesia, blocks post-injury facilitation. Anesthesiology 1993; 78: 713-21.
14 Richmond CE, Bromley LM, Woolf CJ. Preoperative morphine pre-empts postoperative pain. Lancet 1993; 342: 73-5.

15 Tverskoy $M$, Cozacov $C$, Ayache $M$, Bradley $E L J r$, $K i s s i n 1$. Postoperative pain after inguinal herniorrhaphy with different types of anesthesia. Anesth Analg 1990; 70: 29-35.

16 Wilson RJT, Leith S, Jackson IJB, Hunter D. Pre-emptive analgesia from intravenous administration of opioids. Anaesthesia 1994; 49: 591-3.

17 Dabl JB, Hansen BL, Hjortsø NC, Erichsen CJ, Moiniche $S$, Keblet $H$. Influence of timing on the effect of continuous extradural analgesia with bupivacaine and morphine after major abdominal surgery. $\mathrm{Br} \mathrm{J}$ Anaesth 1992; 69: 4-8.

18 Shirasaka $C$, Tsuji $H$, Asoh $T$, Takeuchi $Y$. Role of the splanchnic nerves in endocrine and metabolic response to abdominal surgery. Br J Surg 1986; 73: 142-5.

19 Keblet $H, D a b l J B$. Preemptive analgesia: is it effective in clinical pain states? In: Gebhart GF (Ed.). Visceral Pain, Progress in Pain Research and Management, Vol 5. Seattle: IASP Press, 1995; 489-504.

20 Aanonsen LM, Wilcox GL. Nociceptive action of excitatory amino acids in the mouse: effects of spinally administered opioids, phencyclidine and Sigma agonists. J Pharmacol Exp Ther 1987; 243: 9-19.

21 Murray $C W$, Cowan $A$, Larson $A A$. Neurokinin and NMDA antagonists (but not a kainic acid antagonist) are antinociceptive in the mouse formalin model. Pain 1991; 44: 179-85.

22 Woolf CJ, Thompson SWN. The induction and maintenance of central sensitization is dependent on $\mathrm{N}$ methyl-D-aspartic acid receptor activation: implications for the treatment of post-injury pain hypersensitivity states. Pain 1991; 44: 293-9.

23 Ren $K$, Hylden LK, Williams GM, Ruda $M A$, Dubner $R$. The effects of a noncompetitive NMDA receptor antagonist, $\mathrm{MK}-801$, on behavioral hyperalgesia and dorsal horn neuronal activity in rats with unilateral inflammation. Pain 1992; 50: 331-44.

24 Yamamoto T, Yaksh TL Spinal pharmacology of thermal hyperesthesia induced by constriction injury of sciatic nerve: excitatory amino acid antagonists. Pain 1992; 49: 121-8.

25 Wall $P D$. The prevention of postoperative pain (Editorial). Pain 1988; 33: 289-90.

26 Woolf CJ. Recent advances in the pathophysiology of acute pain. Br J Anaesth 1989; 63: 139-46.

27 Tverskoy $M, O z \Upsilon$, Isakson $A$, Finger J, Bradley $E L J$, Kissin 1. Preemptive effect of fentanyl and ketamine on postoperative pain and wound hyperalgesia. Anesth Analg 1994; 78: 205-9. 
28 Roytblat L, Korotkoruchko A, Katz I, Glazer $M$, Greemberg $L$, Fisher $A$. Postoperative pain: the effect of low-dose ketamine in addition to general anesthesia. Anesth Analg 1993: 77: 1161-5.

29 Malinopsky J-M, Lepage J- $\Upsilon$, Cozian A, Mussini J-M, Pinaudt $M$, Souron $R$. Is ketamine or its preservative responsible for neurotoxicity in the rabbit? Anesthesiology 1993; 78: 109-15.

30 Brock-Utne JG, Mankowitz E, Kallichurum S, Downing JW. Effects of intrathecal saline and ketamine with and without preservative on the spinal nerve roots of monkeys. S Afr Med J 1982; 61: 360-1.

31 Brock-Utne JG, Kallichurum S, Mankowitz E, Mabaraj R], Downing JW. Intrathecal ketamine with preservative - histological effects on spinal nerve roots of baboons. S Afr Med J 1982; 61: 440-1. 